\title{
'Thang bun': indigenous practice of in situ biochar preparation-cum-application for improved jhum cultivation in North East India
}

\author{
H. C. Hombegowda*, Praveen Jakhar, M. Madhu and Yearbok Marwein
}

Thang bun is a traditional agricultural method practised by ethnic communities in Meghalaya, India. This method produces and incorporates biochar in the soil on raised beds from slashed plant biomass while practicing jhumming (slash and burn agriculture). The biochar prepared and incorporated into jhum soils acts as an acid-neutralizing agent and improves physico-chemical properties in acidic soils. This practice highlights the knowledge of ethnic communities on biochar preparation as well as soil fertility management using locally available resources for improving crop performance. This low-cost traditional technology is used to convert surplus slashed biomass into biochar through which the soil is enriched with nutrients, especially potassium and large quantities of carbon is sequestered annually. This traditional practice is the best example of a carbon-negative technology and effective utilization of locally available resources for better crop production. This practice has thrived for several centuries due to its multi-fold significance, minimum degrade effects and higher productive output. Presently, a scientifically modified version of this practice can be adopted for acid soil management in north east hill region of India.

Keywords: Biochar preparation, ethnic communities deforestation, indigenous farming practice, jhum cultivation.

'SLASH-AND-BURN agriculture' (locally known as 'jhum' cultivation in the North Eastern Hill (NEH) region of India) is the most ancient and traditional system of subsistence farming practice followed by the ethnic communities $^{1,2}$. Clearing and burning of primary or secondary forest for cultivation is the principle driver for deforestation in tropical countries ( $\sim 60 \%$ of total deforestation), including NEH and the Eastern Ghats regions of India ${ }^{3-5}$. In these two regions, jhum is the dominant land-use system in the tribal-dominated areas, where the major chunk of land has sloping topography ( $>15 \%$ land slope) and remote access to modern agriculture system.

\section{Traditional jhum practice}

The jhum practice involves clearing and burning of vegetation followed by crop cultivation for two or more years before abandoning the land for restoration of soil fertility

H. C. Hombegowda and M. Madhu are in the ICAR-Indian Institute of Soil and Water Conservation, Research Centre, Koraput 763 002, India, Praveen Jakhar is in the ICAR-Central Institute for Women in Agriculture, Bhubaneswar 751 003, India; Yearbok Marwein is in the ICAR Research Complex for NEH Region, Umiam 793 103, India.

*For correspondence. (e-mail: hombegowdaars@gmail.com) and resiliency, and moving to a new site to repeat the same practice ${ }^{6}$. Once the abandoned site regains soil fertility, the tribal cultivators come back to it for cultivation of the next crop and this is called the jhum cycle. During ancient times, jhum cultivation was proven to be sustainable, and regarded as an ecologically and economically feasible system due to the abundant forest land surrounded by low population density that encouraged to adopt long jhum cycle ( $\sim 40-60$ years, providing enough time to restore soil fertility $)^{7-9}$. According to recent estimates during $2015-16,0.26 \%$ ( $0.85 \mathrm{~m} \mathrm{ha})$ of the total geographical area of India covering 11 states is under jhum cultivation ${ }^{10}$. Of this, $96 \%$ falls under $\mathrm{NEH}$ region. The major direct and indirect effects are loss of forest cover and biodiversity, accelerated soil erosion, decreased soil depth, drying up of springs, silting of tanks, poor soil health and environmental degradations ${ }^{11-13}$. Land degradation due to soil erosion is also a major concern. In India, soil loss from the jhum sites varies from 84 to 170 tonne $\mathrm{ha}^{-1}$ year $^{-1}$ depending on physiographic and anthropogenic factors ${ }^{7,12,14}$. Due to the regular practice of jhum and its negative impacts, the NEH region and the Eastern Ghats of Odisha experience double the rate of land degradation than the national average ${ }^{10}$, which is responsible for transmuting biodiversity-rich productive forests into degraded scrubland ${ }^{15}$. 


\section{Reasons for jhum cultivation}

During human history, most of the acidic soil regions (basically humid regions) adopted jhum cultivation, which ensures fast conversion of nutrients from plant biomass in the soil. This improves the availability of essential nutrients to a great extent and reduces soil acidity during the next cropping season, thus paving the way for better crop production ${ }^{16,17}$. Since ancient times, this technique has been used throughout the humid regions of the tropics across the world for better crop production. This way it overcomes the inherent acidity and poor soil fertility and its practical utility is more economical than any other technique for acidic soil management ${ }^{18}$. Hence, this might be one of the reasons that jhum cultivation became a common agricultural practice for acidic soils in the NEH region and some pockets in the Eastern Ghats region of India. Other factors which contributed to this practice are geographical remoteness, socio-economic backwardness and cultural relationship with jhum.

On the other hand, from a scientific point of view, most of the nutrients are being lost during the process of open burning. Also, open burning causes high soil temperature $\left(>400^{\circ} \mathrm{C}\right)$, which significantly affects the structural stability and loss of soil organic biomass ${ }^{19,20}$. Additionally, crop cultivation for 2 or 3 years and high degree of slope induce higher rate of soil erosion and humus decomposition, which deplete soil fertility status at a fast pace. To overcome the low crop production difficulties, temporally and spatially jhum system has undergone many local modifications, mainly soil and crop management practices for improving soil fertility and to maintain crop productivity in jhum sites ${ }^{18}$.

'Thang bun' is among the indigenous (folk) agricultural methods practised by the ethnic communities in Meghalaya, India, that helps in sustaining soil fertility while maintaining optimum crop productivity in the degraded jhum lands. Presently very little is documented about this practice scientifically. Some researchers have reported about common issues of this practice, like soil nutrient status and crop performance without identifying the scientific rationale behind $\mathrm{it}^{17,21,22}$. The present article identifies the scientific reasoning and context regarding the practice of thang bun in Meghalaya.

\section{Biochar in agriculture}

Biochar is charcoal prepared using plant biomass through slow thermal decomposition (slow pyrolysis $<300^{\circ} \mathrm{C}$ ). It is rich in carbonaceous material having high porosity vis-à-vis surface area that improves the sorption character. Additionally, biochar possesses high resident time, relatively stable (largely resistant to decomposition) and good composition of carbon, nitrogen, potassium, calcium, etc. Soil application of biochar can improve carbon sequestration and soil fertility through altering soil che- mical, physical and biological properties ${ }^{23}$. In recent decades, biochar is recommended as amendment for acidic soil management due to its high buffering capacity $(\mathrm{pH}$ stabilization) and in improving soil functions (amelioration properties) for obtaining higher agronomic yield, while avoiding unfavourable effects of the soil. It is widely recommended as an organic amendment for improving soil fertility. Many studies across the globe confirmed the usefulness of adding biochar in improving the physico-chemical and biological properties of the soil and in mitigating global warming ${ }^{24-27}$.

\section{Jhum cultivation in Meghalaya}

About $70 \%$ of the Meghalaya state is covered with forests. These forests cover both mountain as well as lowland areas of the state forming distinct eco-region of subtropical and tropical respectively. The state is the wettest region of India, recording an average of 12,000 $\mathrm{mm}$ (470 inch) of rainfall a year. The forests are notable for their biodiversity of mammals, birds and plants. The topography of Meghalaya comprises landscapes that have a blend of mountain and plateau regions. The altitude of these plateaus ranges from 150 to $1961 \mathrm{~m}$. The climate, vegetation, relief and regolith constituting the ecosystem significantly influence the paedogenesis, resulting in the development of different kinds of soils. The state is covered by the warm per-humid agro-ecoregion. However, with respect to air temperature it can be divided into two distinct sub eco-regions (zones), viz. thermic and hyperthermic regimes. In Meghalaya due to very high rainfall and sloping topography, the soils are highly weathered and characterized by strong acidity, poor fertility and low clay activity ${ }^{17,22}$. These soil properties are the basic limitations for poor crop cultivation in these high-rainfall regions $^{24}$. Jhum-induced erosion along with shortened jhum cycles contribute largely to land degradation problems in the state. However, the ethnic communities are sustaining optimum crop productivity of these jhum lands for centuries through their indigenous knowledge, e.g. 'thang bun', a modified jhum practice without using much external inputs ${ }^{17,21,22}$. To overcome the difficulties of maintaining crop productivity at the region level, people of this region have identified/innovated this soil-crop management practice that sustains soil and environment with sustainable crop productivity. Even though this region has been practicing jhum cultivation intensively during many centuries, the jhum fields are not degraded in proportion to the real negative impact of jhum practice on soil properties.

\section{Study site}

The thang bun system was studied for a two-year period (2018-20) in three tribal villages, namely Raitong, 
Nonglum and Umlangling (East Khasi Hills region), Meghalaya (Figure 1). Soil type at the study sites was Alfisols. We recorded all the cultural practices/operations carried out during crop cultivation, quantity of slashed biomass, biochar preparation and its addition, physicochemical changes in the soil properties before and after harvest in the six-year jhum cycle study sites. During the study period ginger (Zingiber officinale), potato (Solanum tuberosum) and upland paddy (Oryza sativa) crops were cultivated. For comparison of soil and yield parameters, some plots cultivated using the open burning method were used for the study.

\section{The concept of 'thang bun'}

Thang bun is an indigenous or traditional ancient method of land preparation and crop production in jhum lands,

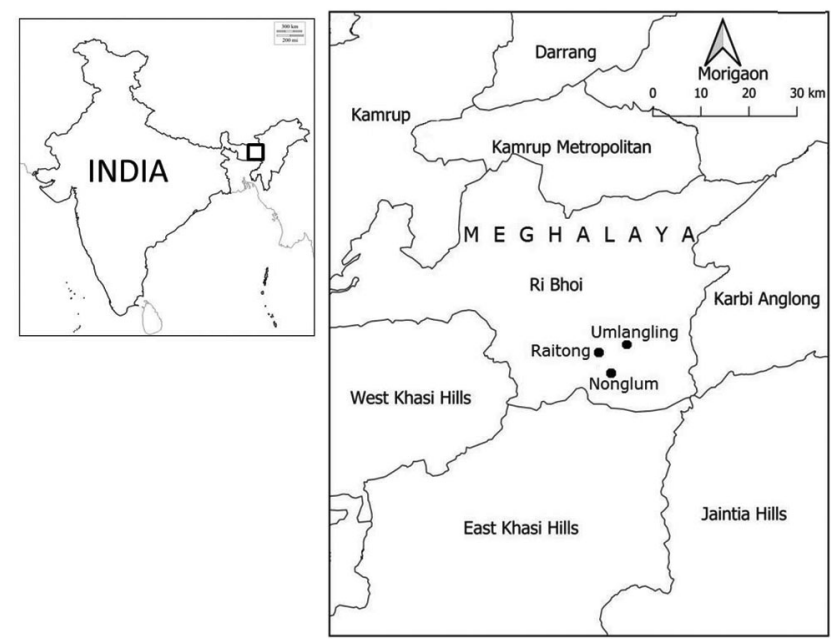

Figure 1. Geographic location of the three study sites in the East Khasi Hills region of Meghalaya, India.

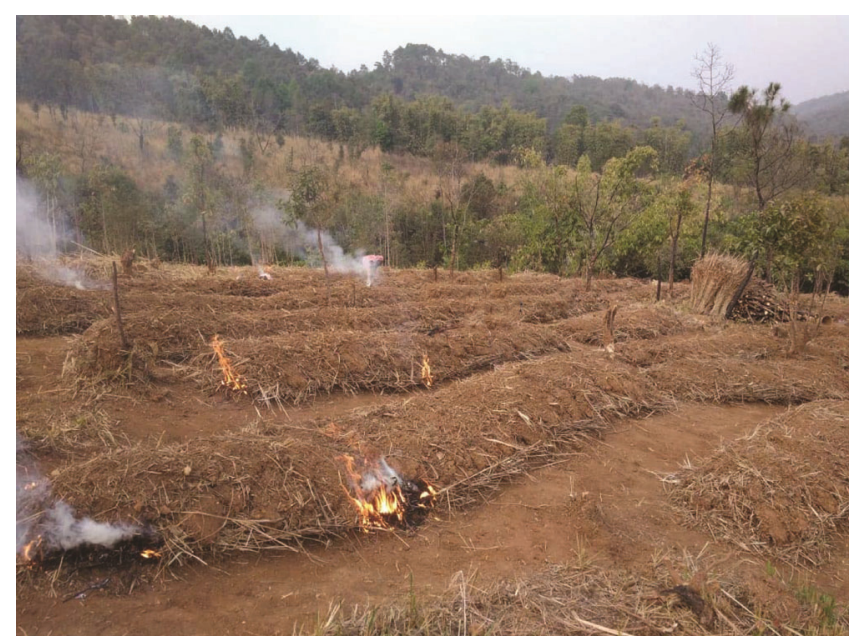

Figure 2. Raised soil beds with buried dried slash biomass and its burning using thang bun method. where dried plant biomass obtained during slashing is heaped or piled at $0.8-1.2 \mathrm{~m}$ width and $4-7 \mathrm{~m}$ length (Figure 2). This biomass is smeared with soil layer at the top to give the shape of raised beds. The biomass is burnt under limited oxygen environment to convert it (through thermo-chemical processes) into charcoal (biochar). Before sowing/planting of crops, biochar is mixed in the soil beds. Dried plant biomass basically consisting small branches, leaves, shrubs, herbs, grasses and pine needles (except wood logs and larger sized branches) having less than $20 \mathrm{~mm}$ diameter, obtained during clearing (slashing) of secondary forest for jhum cultivation is used for preparing raised beds. The plant biomass-covered soil acts as a shield against oxygen supply (Figure 2), and in the partial absence of oxygen (pyrolysis) plant biomass is converted into charcoal through carbonization process. During this method, biochar is prepared and added in the raised beds for crop cultivation during the first year jhum land preparation. This method of land preparation followed by burning has been carried out since many centuries by the ethnic tribal communities (in Meghalaya) and is locally called thung bun. In the local Khasi language the word 'bun' means method of raised bed preparation using biomass followed by burning. This system is also called as 'nur bun' in the Khasi language. In Meghalaya, thang bun is practised by the ethnic communities of Khasi and Jaintia hilly region. It is a modified form of the traditional jhum cultivation. The history of the beginning of this practice is not clearly known. According to the native tribal farmers in Meghalaya, this is an ancient practice and the present knowledge has been transferred from their forefathers. Since thang bun is a modified method of jhum cultivation, we can presume that it is as old as the jhum method. According to tribal farmers, during last century thang bun practice was limited to a small scale in lowland areas, where the land had less soil fertility and crop productivity. During the last century, the shortened jhum cycle $(\sim 15-20$ years $)$ has resulted in reduced recovery of soil fertility at most jhum sites. According to recent studies ${ }^{7}$, the shifting cycle has been further reduced to 5-6 years resulting in further decline in the recovery of soil fertility. To maintain crop production at an optimal level, the tribal farmers have started practising thang bun method regularly in larger areas compared to cultivation in earlier decades.

\section{Thang Bun and Amazon terra preta soils - a comparative analysis}

The thang bun method is the outcome of traditional tribal farmers' knowledge of oxygen limited (underneath soil) biomass burning for improving soil fertility and achieve sustainable crop production in acidic soil. A similar kind of ancient practice (enriching poor soils with biochar) is reported from the Amazon basin ${ }^{28}$. Based on long-term 
studies, many researchers have provided evidence for man-made fertile soil called dark earth (terra preta) in numerous sites (around 50,000 ha) in the Amazon basin. These dark earths are composed of highly stable organic black carbon material (biochar) of variable quantity and these fertile soils help in achieving agricultural sustainability $^{29}$. Such dark earths are also reported from Araracuara in Caqueta basin, Colombian ${ }^{30}$; East Kalimantan basin, Indonesia ${ }^{31}$ and Murray river basin, SE Australia ${ }^{32}$. This terra preta exploration study around the world provided sufficient evidence on the knowledge of ancient people to improve soil fertility for sustainable agriculture from infertile acidic soils. All these terra preta sites belong to native aboriginals, where the history of practice of slash-and-burn agriculture exists. Fearnside ${ }^{33}$ reported that, 2.6 tonne $\mathrm{ha}^{-1}$ of black carbon were added during open burning with a forest biomass of 90-100 tonne ha ${ }^{-1}$ in the Amazon region. The lower yield of black carbon during open burning is due to the conversion of majority of biomass (around 95\%) into ash and yielding around $5 \%$ of black carbon. To establish average black carbon stock of 50 tonne $\mathrm{ha}^{-1}$ of terra preta, one needs more than 25 burnings of primary forests with good standing forest biomass. Woods and $\mathrm{McCann}^{34}$ reported that open burning during shifting cultivation does not add black carbon (biochar) equal to terra preta soils. Based on the above reports and evidence from the present study we argue that to make terra preta soils, the aboriginals in Amazon may have adopted a method similar to thang bun, i.e. soilcovered biomass burning. By adopting thang bun method, one can generate black carbon stock of 50 tonne ha $^{-1}$ from the oxygen-limited burning of standing forest biomass (100-120 tonne $\mathrm{ha}^{-1}$ ) gained during long rotation.

\section{In situ biochar preparation through modified jhumming}

In this method, the tribal farmers clear the secondary forest or vegetation during December-January and allow it to dry. After a period of 15-20 days, they pile up dried branches, shrubs, herbs and grasses approximately 1.0 $1.2 \mathrm{~m}$ wide, $4-7 \mathrm{~m}$ long and $0.2-0.3 \mathrm{~m}$ height as raised soil beds (Figure 2) spaced about 1.0-1.5 m apart. During pilling, all plant-shed residues (branches, leaves, shrubs, herbs and grasses) are mixed and used equally for the bed preparation and placed closely without giving much space. Above this biomass bed, a thick layer (about $4 \mathrm{~cm}$ ) of dried grass (sods) is covered like a mat to avoid downward movement of top layer/cover of soil. Further, the pilled biomass is covered by $4-7 \mathrm{~cm}$ thick soil layer, scrapped from the space between the two beds (Figure 2). Soil with intact roots is scraped and laid upside down on the biomass bed. Now the soil-covered biomass bed is sealed from the top, except the sides (Figure 2). To aggravate fire, additionally dried grass is provided from the side of the bed. As this grass burns quickly, it makes small openings for the escape of smoke and entry of air. After completion of raised beds preparation, the buried grass is burnt from the sides of the beds (Figure 2). In this oxygen-limited (anaerobic) burning process, the buried biomass is converted to biochar on the raised beds (Figures 3 and 4). The thermo-chemical process takes hours to days depending on the quantity and quality of plant biomass added in the bed. Soon after the bed cools down, planting activities are done on the raised beds. Jhum practising ethnic communities in Meghalaya skillfully carry out all the above operations and produce good quantity of biochar in the beds. Since different types of plant biomass materials are used for this process, the prepared biochar in the beds is not of uniform quality. During the whole burning process around $15-20 \%$ of the plant biomass from the sides of the bed is converted into ash and majority of the soil-covered biomass is converted into biochar (Figure 4).

For this method of bed preparation, biomass arrangement and burying process require a skillful and experienced person. This method requires more manpower and time than the open burning practice. Hence, this practice is limited to small patches of land (around 0.1$0.4 \mathrm{ha}$ ). Even though this process is laborious, currently it is adopted to a large extent in short jhum cycle sites. Tribal farmers customarily use this method during the first year of the jhumming and many of them repeat it during the next jhumming cycle. The repetition of this method in the second jhumming cycle depends on the period of the cycle. All tribes who conduct short jhum cycles (5-6 years) opt for this practice to get more yield than the long cycle (above 12 years).

By following indigenous thang bun practice, ethnic communities are unknowingly adding varied quality and quantity (depending on the jhum cycle, slash materials

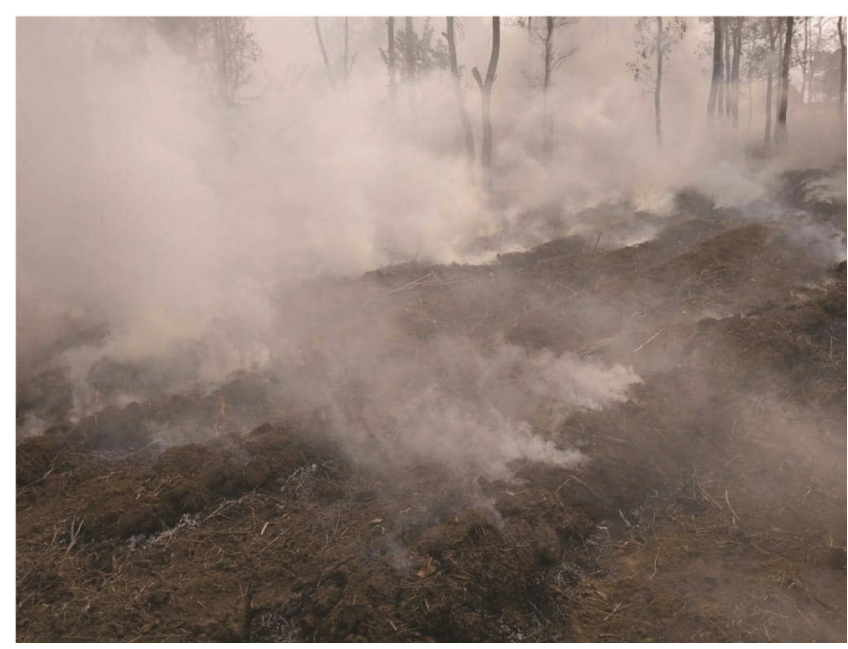

Figure 3. Limited oxygen burning of buried dried plant biomass using thang bun method. 
Table 1. Yield of different crops during different years of thang bun cultivation

\begin{tabular}{|c|c|c|c|}
\hline \multirow[b]{2}{*}{ Cultivation practice } & \multicolumn{2}{|c|}{ First year yield (tonne $\mathrm{ha}^{-1}$ ) } & \multirow{2}{*}{$\frac{\text { Second year yield (tonne } \mathrm{ha}^{-1} \text { ) }}{\text { Upland paddy }}$} \\
\hline & Ginger & Potato & \\
\hline Jhum cultivation (open burning) & $2.87 \pm 0.19^{\mathrm{a}}$ & $5.68 \pm 0.3^{\mathrm{a}}$ & $0.752 \pm 0.01^{\mathrm{a}}$ \\
\hline Thang bun (in situ biochar application) & $3.93 \pm 0.14^{\mathrm{b}}$ & $7.35 \pm 0.2^{b}$ & $1.293 \pm 0.01^{\mathrm{b}}$ \\
\hline
\end{tabular}

Mean \pm standard error; for each crop yield the letters indicate significant differences $(P<0.05$; one-way analysis of variance) between thang bun and open burn of jhum cultivation.

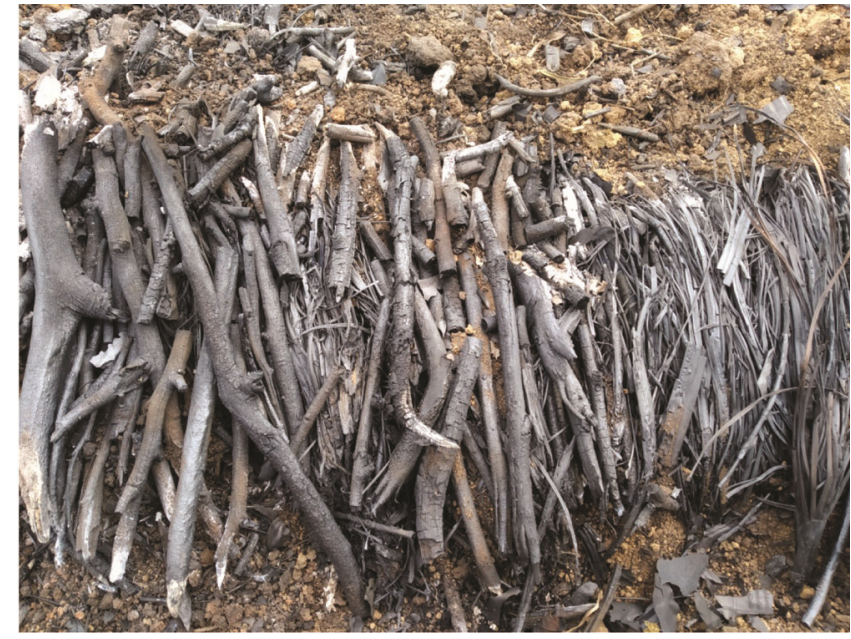

Figure 4. Biochar prepared from grasses and small branches during oxygen-limited burning in raised beds.

and litter quality) of biochar to the jhum system. Due to the addition of biochar, the thang bun system improves physical, chemical and biological properties of soil and also crop production. Once the soil fertility status declines, i.e. after 2-3 years of cultivation, farmers abandon the land for regeneration.

\section{Quantity of plant biomass and biochar added}

In our 6-year-old jhum cycle study plots, the quantity of dry plant biomass (slashed material) obtained for raised bed preparation varied from 6.4 to 10.4 tonne ha ${ }^{-1}$. The plant biomass basically consists of small branches, leaves, shrubs, herbs, grasses and pine needles (except wood logs and larger sized branches) having less than $20 \mathrm{~mm}$ diameter. From this biomass, the quantity of biochar added in the raised bed varies from 1.8 to 3.2 tonne ha ${ }^{-1}$. Madhu et al. ${ }^{12}$ reported that 6 and 12 years of jhum cycle generate about 5.9 and 56.4 tonne $\mathrm{ha}^{-1}$ of biomass respectively. Also many studies around the globe have recommended the application of 2-3 tonne $\mathrm{ha}^{-1}$ of biochar as amendment for achieving good crop yield ${ }^{23,24}$. The quantity of biochar added during the thang bun method depends on the jhum cycle. During recent years in India, around $76 \%$ and $24 \%$ of tribal farmers have been practising 5-6 (short) and 10-12 years (medium) of jhum cycle respectively ${ }^{12}$. The reduced jhum cycle has a direct

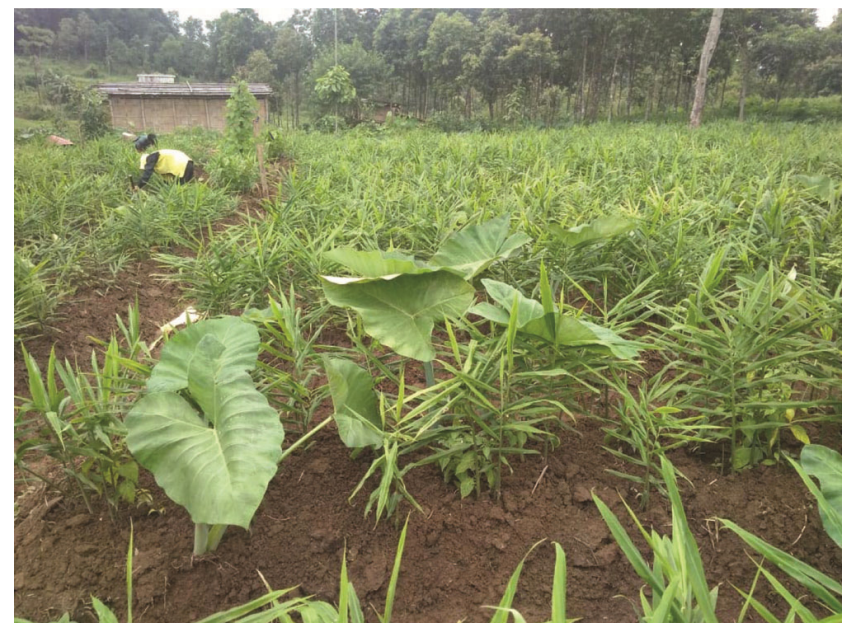

Figure 5. Luxuriant growth of ginger crop during the first year of thang bun cultivation.

impact on the availability of biomass for the thang bun practice $^{35}$.

\section{Improved crop performance}

All these land preparation activities (like cleaning, raised bed preparation and burning) are completed during January to March and sowing is done soon after the premonsoon showers, i.e. summer season rainfall (MayJune). During the first year the beds prepared using the above techniques are utilized for ginger and potato cultivation (Figure 5). During the second year the farmers grow upland paddy and vegetables like chilli, yam, tomato, bottle guard, pumpkin, etc. After the burning process, crops are cultivated according to the traditional method without using much external inputs. Table 1 provides details of crop and yield obtained during two years of cultivation. A comparison between the yields of crops obtained under two types of jhum system is also given in the table. As described earlier, in Meghalaya during the process of jhumming the crop cultivation pattern varies every year. A scrutiny of the statistically analysed data in Table 1 indicates that under thang bun cultivation, root crops gave significantly higher yields in comparison to open burnt jhum cultivation (ginger: $37 \%$ and $29 \%$ respectively). In case of upland paddy, the increase was to the tune of $72 \%$ in the second year of study. The significant 
Table 2. Properties of $0-25 \mathrm{~cm}$ soil depth in raised beds during thang bun cultivation

\begin{tabular}{lccc}
\hline Parameters & First year $(\mathrm{bb})$ & First year $(\mathrm{ab})$ & Second year end \\
\hline pH $(1: 2.5)$ & $4.28 \pm 0.07^{\mathrm{a}}$ & $5.52 \pm 0.06^{\mathrm{b}}$ & $4.73 \pm 0.04^{\mathrm{c}}$ \\
SOC $(\%)$ & $1.63 \pm 0.32^{\mathrm{a}}$ & $2.76 \pm 0.38^{\mathrm{b}}$ & $2.04 \pm 0.31^{\mathrm{ab}}$ \\
$\mathrm{CEC}\left(\mathrm{cmol} \mathrm{kg}^{-1}\right)$ & $7.28 \pm 1.15^{\mathrm{a}}$ & $10.65 \pm 0.62^{\mathrm{b}}$ & $9.83 \pm 0.34^{\mathrm{b}}$ \\
$\mathrm{BD}\left(\mathrm{mg} \mathrm{m}^{-3}\right)$ & $1.41 \pm 0.09^{\mathrm{a}}$ & $1.16 \pm 0.05^{\mathrm{b}}$ & $1.24 \pm 0.04^{\mathrm{b}}$ \\
Available N $\left(\mathrm{mg} \mathrm{kg}^{-1}\right)$ & $143.6 \pm 8.9^{\mathrm{a}}$ & $319.1 \pm 7.3^{\mathrm{b}}$ & $192.5 \pm 4.2^{\mathrm{c}}$ \\
Available P $\left(\mathrm{mg} \mathrm{kg}^{-1}\right)$ & $3.60 \pm 0.38^{\mathrm{a}}$ & $8.86 \pm 0.47^{\mathrm{b}}$ & $5.23 \pm 0.45^{\mathrm{c}}$ \\
Available K $\left(\mathrm{mg} \mathrm{kg}^{-1}\right)$ & $156.5 \pm 5.6^{\mathrm{a}}$ & $387.4 \pm 7.4^{\mathrm{b}}$ & $238.1 \pm 6.9^{\mathrm{c}}$ \\
$\mathrm{Na}\left(\mathrm{cmol}\left(\mathrm{p}^{+}\right) \mathrm{kg}^{-1}\right)$ & $0.27 \pm 0.04^{\mathrm{a}}$ & $0.39 \pm 0.02^{\mathrm{b}}$ & $0.28 \pm 0.02^{\mathrm{a}}$ \\
$\mathrm{Ca}\left(\mathrm{cmol}\left(\mathrm{p}^{+}\right) \mathrm{kg}^{-1}\right)$ & $0.45 \pm 0.1^{\mathrm{a}}$ & $2.23 \pm 0.2^{\mathrm{b}}$ & $1.08 \pm 0.2^{\mathrm{c}}$ \\
$\mathrm{Mg}\left(\mathrm{cmol}\left(\mathrm{p}^{+}\right) \mathrm{kg}^{-1}\right)$ & $0.47 \pm 0.1^{\mathrm{a}}$ & $1.02 \pm 0.2^{\mathrm{b}}$ & $0.63 \pm 0.1^{\mathrm{a}}$ \\
$\mathrm{Al}\left(\mathrm{cmol}\left(\mathrm{p}^{+}\right) \mathrm{kg}^{-1}\right)$ & $1.56 \pm 0.2^{\mathrm{a}}$ & $0.23 \pm 0.1^{\mathrm{b}}$ & $0.58 \pm 0.1^{\mathrm{c}}$ \\
\hline
\end{tabular}

$\mathrm{bb}$, Before burning, ab, After burning; for each soil chemical parameter the letters indicate significant differences $(P<0.05$; one-way analysis of variance) between the three stages of soil sampling (first year before and after burning, and second year end soil sample analysis).

increase in yield under thang bun can be attributed to improved soil physico-chemical properties such as soil acidity, cation exchange capacity (CEC), soil fertility, microbial activity, water-holding capacity, bulk density and soil porosity. The slow burning mechanism during biochar formation in beds helps in better crop root growth and yield due to the control of soil pests ${ }^{23,27}$. Similar increase in crop yield has been reported under thang bun method of cultivation by Upadhaya et $a l^{22}$. Biochar improves soil fertility and provides nutrition to the crops as well as improves the soil physical and biological properties which help in better crops yield ${ }^{23,36}$.

\section{Improved soil properties}

During land preparation process for jhum cultivation, biochar is prepared and added in situ through indigenous method of raised bed planting. Enriching of jhum fields with biochar bears a direct positive effect on soil physicochemical properties. Table 2 gives a few important soil physico-chemical properties of the study sites.

\section{Soil pH}

In the thang bun study sites, addition of biochar significantly improved soil $\mathrm{pH}$ (Table 2). Although the overall $\mathrm{pH}$ remained in the acidic range (4.73-5.52), improvement over control was significant. The improvement of $\mathrm{pH}$ of highly weathered soil can be attributed to the alkaline nature $(\mathrm{pH}>9)$ of biochar ${ }^{37}$ and release of the base cations $^{24,25,27}$. The high liming potential and buffering effect of biochar on soil $\mathrm{pH}$ have been reported by many studies across the globe. The reported effects of biochar are acid-neutralizing property, increase in base saturation and improvement of $\mathrm{CEC}^{24,37}$. These improvements are subject to the basic properties of the soil and biochar type. Also, the improved soil $\mathrm{pH}$ strongly controls the microbial-mediated denitrification in the soils ${ }^{38}$. This altered $\mathrm{pH}$ has a significant impact on enhanced availability of nutrients for plant growth observed during two years of jhum cultivation. The present study corroborates the results of Majumdar et al. ${ }^{17}$ carried out under similar thang bun method of cultivation, as well as Yuan et al. ${ }^{37}$, and Jien and Wang ${ }^{25}$ under biochar-added general cropping. It is significant to observe that after the second year crop harvest, the $\mathrm{pH}$ returned to acidic conditions. This may be attributed to reduction in the neutralizing effects of biochar in later stages.

\section{Soil fertility}

Table 2 presents the impact of thang bun on important soil fertility parameters, viz. available nitrogen, phosphorus and potassium $(\mathrm{N}, \mathrm{P}, \mathrm{K})$ and soil organic carbon (SOC). Under biochar-added soils, there was significant improvement of soil fertility parameters such as SOC, CEC and essential nutrients status. In the first year after biochar application, the net improvement observed in $\mathrm{N}$, $\mathrm{P}, \mathrm{K}$ and SOC was to the tune of $53 \%, 187 \%, 237 \%$ and $69 \%$ respectively. The improved availability of essential nutrients in the soil is a result of nutrient conversion from plant biomass to soil medium, and changes in soil materials from heating ${ }^{20}$. Additionally, oxygen limited burning at a moderate temperature causes high nutrient release to the soil instead of loss through volatilization in open burning method with high temperature ${ }^{8,13}$. This method also facilitates nutrient retention and inhibits nutrient leaching, specially nitrate. Similar improvement in the chemical properties of biochar-added soils has been reported $^{24,39}$. In subsequent years, all the studied fertility parameters showed significant decrease in their values. The decreased fertility is mainly due to nutrients utilization by the cultivated crops, leaching along with nutrient erosion during crop cultivation. 


\section{Cation exchange capacity}

CEC showed a significant improvement by $46 \%$ in the first year of biochar treatment and thereafter slight downward trend (non-significant decrease). The improvement of specific surface area (SSA) of biochar-added soil is due to the porous structure of biochar and the increased number of carboxylic groups added due to slow oxidation, resulting in the improvement of CEC in the biocharadded soil. In a similar study, Yuan et al. ${ }^{37}$ reported substantial increase in CEC and exchangeable cations under biochar-amended soils and consequently, improvement in soil fertility was observed. Soil analysis was done for important cation, viz. $\mathrm{Na}, \mathrm{Ca}, \mathrm{Mg}$ and $\mathrm{Al}$. During the first year, maximum availability $(1.56 \mathrm{cmol} / \mathrm{kg})$ was observed for Al. However, during the second year calcium availability had peaked (2.23). This cation showed maximum fluctuation in availability during the study. The results of the present study are in agreement with those of Majumdar et $a l .{ }^{17}$ under similar thang bun method, and Atkinson et al. $^{23}$ under biochar-added system, who argued that nutrients in biochar itself brought exchangeable cations into the soil system.

\section{Soil physical properties}

Many studies have been reported on the positive impact of biochar on soil physical properties ${ }^{23}$. Jien and Wang ${ }^{25}$ found a significant decrease in bulk density and increase in mean weight diameter of soil aggregates, porosity and hydraulic conductivity. In the present study, a significant drop in bulk density to the tune of $17.7 \%$ and its sustainability in the range $1.16-1.24 \mathrm{mg} \mathrm{m}^{3}$ were observed in subsequent years. The decrease in bulk density of biochar-added soils due to modifications in diameter of soil aggregates $^{23,40}$ and flocculation of soil microaggregates ${ }^{25}$, this also led to increase in porosity and surface area. Sun and $\mathrm{Lu}^{41}$ demonstrated that biochar addition to clayey soils increased the aggregate stability, reorganization of pore-size distribution and soil water retention that improve the overall poor physical characteristics of clayey soil. The mucilage produced by microbial activity and the biochar surface that contains carboxylic and hydroxyl groups, can function as a binding agent that attaches soil microaggregates to form larger macroaggregates ${ }^{25}$.

\section{Other soil properties}

Apart from soil chemical properties, microbial activities have also been found to improve in biochar-added soils $^{26,42}$. Xu et al. ${ }^{43}$ reported that microbial biomass carbon started to increase after a few days of biochar addition and maintained microbial activity for a longer period. This increase in microbial growth and activity in biochar-amended soil could be due to the favourable environment created by the altered soil $\mathrm{pH}(5.0-6.0)$ and improved physico-chemical properties of the soil. Jien and $\mathrm{Wang}^{25}$, and Lehmann et al. $^{26}$ also indicated that the improved microbial activities are due to high porosity, increased food source for microbes and high concentration of macrospores of biochar particles. They also reported the significant positive correlation between microbial biomass carbon and soil $\mathrm{pH}$. Lehmann et al. ${ }^{26}$ reported improvement in the habitation of mycorrhiza fungi as well as soil quality.

\section{Soil erosion control}

The improved physical properties of biochar-added soil are significantly correlated with decreased soil loss rate in highly weathered soils ${ }^{25}$. Several studies showed that improved soil aggregate stability and macroaggregate formation in biochar-amended soils were important properties in maintaining porosity and reducing soil erosion $^{44,45}$. These studies clearly support the fact that biochar incorporation to soil through thang bun method improves its physical properties in a variety of ways and reduces soil erosion which ultimately contributes to land stability and cease degradation and improves in situ biological activities.

\section{Conclusion}

Thang bun is a traditional agricultural method practised by ethnic communities in Meghalaya. This method produces and incorporates biochar to the soil on raised beds from slashed plant biomass while practicing jhumming. This is the first scientific reporting of an indigenous in-situ biochar preparation cum addition technique for improving soil fertility and crop performance in jhum sites. The biochar prepared and incorporated into jhum soils acts as an acid-neutralizing agent and drastically improves physico-chemical properties in acidic soils. During thang bun practice, the improved physico-chemical properties of soil like $\mathrm{pH}, \mathrm{CEC}$, bulk density and essential soil nutrients show significantly positive effects on crop yield and erosion control. Several studies have reported that crop residues become good biochar. Hence, large-scale adoption of this technology in acidic soils of remote areas can help to effectively utilize the localized crop residues and save energy and transportation costs. This practice highlights the knowledge of ethnic communities on biochar preparation (with different notions), soil acidity, soil fertility and its management using locally available resources for improving crop performance. This low-cost traditional technology is used to convert surplus slashed biomass into biochar through which the soil can be enriched with nutrients, specially potassium and large 
quantities of carbon could be sequestered annually in addition to achieving good yield. This traditional practice is the best example of the carbon-negative technology and effective utilization of locally available resources for better crop production. This practice has thrived for several centuries due to its multifunctional value, minor degradative effects and more productive technology. Presently, a scientifically modified version of this practice can be adopted for acid soil management. This article showcases the folk knowledge of jhum in order to improve acidic soil management.

1. Brookfield, H. and Padoch, C., Appreciating agrodiversity: a look at the dynamism and diversity of indigenous farming practices. Environ.: Sci. Policy Sustain. Develop., 1994, 36(5), 6-45.

2. Padoch, C., Harwell, E. and Sustanto, A., Swidden, sawah, and in-between: agricultural transformation in Borneo. Hum. Ecol., 1998, 26, 3-20.

3. Laurance, W. F., Forest destruction in tropical Asia. Curr. Sci., 2007, 93, 1544-1550.

4. Lele, N. and Joshi, P. K., Analyzing deforestation rates, spatial forest cover changes and identifying critical areas of forest cover changes in North-East India during 1972-1999. Environ. Monit. Assess., 2009, 156(1-4), 159.

5. Myers, N., Tropical forests: the main deforestation fronts. Environ. Conserv., 1993, 20, 9-16.

6. Toky, O. P. and Ramakrishnan, P. S., Secondary succession following slash and burn agriculture in North-Eastern India: I. Biomass, litterfall and productivity. J. Ecol., 1983, 71, 735-745.

7. Hombegowda, H. C., Jakhar, P., Beer, K. and Madhu, M., Status of organic carbon recovery under different fallow periods of shifting cultivated sites in Central Eastern Ghats, India. In Soil and Water Resource Management for Climate Smart Agriculture, Global Food and Livelihood Security, International Conference, Soil Conservation Society of India, New Delhi, 2019, pp. 127132 .

8. Ramakrishnan, P. S., The science behind rotational bush fallow agriculture system (jhum). Proc. Indian Acad. Sci. (Plant Sci.), 1984, 93, 379-400.

9. Toky, O. P. and Ramakrishnan, P. S., Cropping and yields in agricultural systems of the northeastern hill region of India. AgroEcosyst., 1981, 7, 11-25.

10. Wasteland Atlas of India, National Remote Sensing Centre, Indian Space Research Organization, Hyderabad and Department of Land Resources, Ministry of Rural Development, New Delhi, 2019, pp. $1-246$.

11. Hombegowda, H. C., Adhikary, P. P., Jakhar, P., Madhu, M. and Barman, D., Hedge row intercropping impact on run-off, soil erosion, carbon sequestration and millet yield. Nutr. Cycl. Agroecosyst., 2020, 116(1), 103-116.

12. Madhu, M., Hombegowda, H. C., Meena, M. K. and Barla, G. W., Shifting cultivation in Odisha state: issues and challenges. ICARIndian Institute of Soil and Water Conservation, Research Centre, Koraput, Technology Broucher PP-02/KR/E-2016, 2016, pp. 1-33.

13. Mishra, B. K. and Ramakrishnan, P. S., Slash and burn agriculture at higher elevations in north-eastern India. I. Sediment, water and nutrient losses. Agric. Ecosyst. Environ., 1983, 9(1), 69-82.

14. Singh, A. and Singh, M. D., Effect of various stages of shifting cultivation on soil erosion from steep hill slopes. Indian For., 1981, 106(2), 115-121.

15. Adhikary, P. P. et al., Land use and land cover dynamics with special emphasis on shifting cultivation in Eastern Ghats High- lands of India using remote sensing data and GIS. Environ. Monit. Assess., 2019, 191(5), 315.

16. Juo, A. S. and Manu, A., Chemical dynamics in slash-and-burn agriculture. Agric. Ecosyst. Environ., 1996, 58(1), 49-60.

17. Majumdar, B., Satapathy, K. K., Kumar, K. and Patiram, Changes in soil properties under bun cultivation in acidic hill soil of Meghalaya. J. Indian Soc. Soil Sci., 2002, 50(1), 130-132.

18. Moran, E. F., Socio-economic aspects of acid soil management. In Plant-Soil Interactions at Low pH: Principles and Management. Springer, Dordrecht, The Netherlands, 1995, pp. 663-669.

19. Andriesse, J. P. and Koopmans, T. T., A monitoring study on nutrient cycles in soils used for shifting cultivation under various climatic conditions in tropical Asia. I. The influence of simulated burning on form and availability of plant nutrients. Agric. Ecosyst. Environ., 1984, 12, 1-16.

20. Thomaz, E. L., High fire temperature changes soil aggregate stability in slash-and-burn agricultural systems. Sci. Agricola, 2017, 74(2), 157-162.

21. Chhetry, G. K. N. and Belbahri, L., Indigenous pest and disease management practices in traditional farming systems in north east India - a review. J. Plant Breed. Crop Sci., 2009, 1(3), 28-38.

22. Upadhaya, K., Barik, S. K., Kharbhih, V. M., Nongbri, G., Debnath, G., Gupta, A. and Ojha, A., Traditional bun shifting cultivation practice in Meghalaya, Northeast India. Energy, Ecol. Environ., 2020, 5(1), 34-46.

23. Atkinson, C. J., Fitzgerald, J. D. and Hipps, N. A., Potential mechanisms for achieving agricultural benefits from biochar application to temperate soils: a review. Plant Soil, 2010, 337 (1-2), 1-18.

24. Chintalaa, R., Mollinedo, J., Schumacher, T. E., Malo, D. D. and Julsonb, J. L., Effect of biochar on chemical properties of acidic soil. Arch. Agron. Soil Sci., 2014, 60(3), 393-404; doi:10.1080/ 03650340.2013.789870

25. Jien, S. H. and Wang, C. S., Effects of biochar on soil properties and erosion potential in a highly weathered soil. Catena, 2013, 110, 225-233.

26. Lehmann, J., Rillig, M. C., Thies, J., Masiello, C. A., Hockaday, W. C. and Crowley, D., Biochar effects on soil biota - a review. Soil Biol. Biochem., 2011, 43, 1812-1836.

27. Xu, R. K., Zhao, A. Z., Yuan, J. H. and Jiang, J., pH buffering capacity of acid soils from tropical and subtropical regions of China as influenced by incorporation of crop straw biochars. J. Soils Sediments, 2012, 12(4), 494-502.

28. McCann, J. M., Woods, W. I. and Meyer, D. W., Organic matter and anthrosols in Amazonia: interpreting the Amerindian legacy. In Sustainable Management of Soil Organic Matter (eds Rees, R. M. et al.), CAB International, Wallingford, UK, 2001, pp. 180189.

29. Glaser, B., Haumaier, L., Guggenberger, G. and Zech, W., The terra preta phenomenon: a model for sustainable agriculture in the humid tropics. Naturwissenschaften, 2001, 88(1), 37-41.

30. Eden, M. J., Bray, W., Herrera, L. and McEwan, C., Terra preta soils and their archaeological context in the Caquetá basin of southeast Colombia. Am. Antiq., 1984, 125-140.

31. Sheil, D. et al., Do anthropogenic dark earths occur in the interior of Borneo? Some initial observations from East Kalimantan. Forests, 2012, 3(2), 207-229.

32. Downie, A. E., Van Zwieten, L., Smernik, R. J., Morris, S. and Munroe, P. R., Terra Preta Australis: reassessing the carbon storage capacity of temperate soils. Agric. Ecosyst. Environ., 2011, 140(1-2), 137-147.

33. Fearnside, P. M., Greenhouse gas emissions from deforestation in the Brazilian Amazon. In Carbon Emissions and Sequestration in Forests: Case Studies from Seven Developing Countries, Report. LBL-32119, US Environmental Protection Agency, Climate Change Division (eds Makundi, W., Sathaye, J. and Masera, O.), Washington, DC, and Lawrence Berkeley Laboratory, Energy and 
Environment Division, Berkeley, California, USA, 1992, pp. 36 47.

34. Woods, W. I. and McCann, J. M., The anthropogenic origin and persistence of Amazonian dark earths. Yearb. Conf. Latin Am. Geogr., 1999, 25, 7-14.

35. Saplalrinliana, H., Thakuria, D., Changkija, S. and Hazarika, S. Impact of shifting cultivation on litter accumulation and properties of jhum soils of North East India. J. Indian Soc. Soil Sci., 2016, 64(4), 402-413.

36. Karer, J., Wimmer, B., Zehetner, F., Kloss, S. and Soja, G., Biochar application to temperate soils: effects on nutrient uptake and crop yield under field conditions. Agric. Food Sci., 2013, 22, 390-403.

37. Yuan, J. H., Xu, R. K., Wang, N. and Li, J. Y., Amendment of acid soils with crop residues and biochars. Pedosphere, 2011, 21(3), 302-308.

38. Obia, A., Cornelissen, G., Mulder, J. and Dorsch, P., Effect of soil $\mathrm{pH}$ increase by biochar on $\mathrm{NO}, \mathrm{N}_{2} \mathrm{O}$ and $\mathrm{N}_{2}$ production during denitrification in acid soils. PLoS ONE, 2015, 23, 10(9), e0138781

39. Boersma, M., Wrobel-Tobiszewskab, A., Murphya, L. and Eyles, A., Impact of biochar application on the productivity of a temperate vegetable cropping system. N.Z. J. Crop Hortic. Sci., 2017, 45(4), 277-288; doi.org/10.1080/01140671.2017.1329745.
40. Obia, A., Mulder, J., Martinsen, V., Cornelissen, G. and Borresen, $\mathrm{T}$., In situ effects of biochar on aggregation, water retention and porosity in light-textured tropical soils. Soil Till. Res., 2016, 1(155), 35-44.

41. Sun, F. and Lu, S., Biochars improve aggregate stability, water retention, and pore-size properties of clayey soil. J. Plant Soil Sci., 2014, 177(7), 26-33.

42. Kolb, S. E., Fermanich, K. J. and Dornbush, M. E., Effect of charcoal quantity on microbial biomass and activity in temperate soils. Soil Sci. Soc. Am. J., 2019, 73, 1173-1181.

43. Xu, N., Tan, G., Wang, H. and Gai, X., Effect of biochar additions to soil on nitrogen leaching, microbial biomass and bacterial structure. Eur. J. Soil Biol., 2016, 74, 1-8.

44. Li, Z. G. et al., The benefic effect induced by biochar on soil erosion and nutrient loss of slopping land under natural rainfall conditions in central China. Agric. Water Manage., 2017, 185, $145-150$.

45. Peng, X., Zhu, Q. H., Xie, Z. B., Darboux, F. and Holden, N. M., The impact of manure, straw and biochar amendments on aggregation and erosion in a hillslope Ultisol. Catena, 2016, 138, 30-37.

Received 9 December 2020; accepted 16 December 2020

doi: $10.18520 / \mathrm{cs} / \mathrm{v} 120 / \mathrm{i} 7 / 1160-1168$ 